\title{
Corticotropin-releasing hormone and extracellular mitochondria augment lgE-stimulated human mast-cell vascular endothelial growth factor release, which is inhibited by luteolin
}

\author{
Shahrzad Asadi ${ }^{1,2}$ and Theoharis C Theoharides ${ }^{1,3,4,5,6^{*}}$
}

\begin{abstract}
Background: Autism spectrum disorders (ASDs) are neurodevelopmental disorders characterized by varying degrees of dysfunctional social abilities, learning deficits, and stereotypic behaviors. Many patients with ASDs have 'allergy-like' symptoms and respond disproportionally to stress. We have previously shown that the peptide neurotensin (NT) is increased in the serum of young children with autism and that can stimulate extracellular secretion of mitochondrial (mt)DNA which was also increased in the serum of these children.

Methods: Human mast cells were stimulated by corticotropin-releasing hormone (CRH), mitochondrial DNA, IgE/anti-lgE, either for 24 hours to measure vascular endothelial growth factor (VEGF) release by ELISA or for 6 hours or quantitative PCR.

Results: CRH augmented IgE/anti-IgE-induced human mast-cell release of VEGF and it also induced the expression of IgE receptor (FcERI) on mast cells. Moreover, sonicated mitochondria also augmented VEGF release, and this effect was blocked by the natural flavone luteolin.

Conclusion: These results indicate that stress and infection-mimicking extracellular mitochondrial components augment allergic inflammation that may be involved in the early pathogenesis of ASDs. Moreover, luteolin inhibits these processes and may be helpful in the treatment of ASDs.
\end{abstract}

\section{Introduction}

Autism spectrum disorders (ASDs) are pervasive developmental disorders for which no distinct pathogenesis, biomarkers, or effective treatment have been identified. ASDs involve some immune dysfunction in the patient [1] or in the mother during gestation [2], and may have a neuroimmune component [3]. Many children with ASDs also have atopic features [4] or food allergies [5-7] that present as 'allergy-like' symptoms $[7,8]$. Such symptoms often occur in the absence of increased serum IgE levels or positive skin-prick tests, suggesting mast-cell activation by non-immune triggers [9]. Increased

\footnotetext{
* Correspondence: theoharis.theoharides@tufts.edu

${ }^{1}$ Molecular Immunopharmacology and Drug Discovery Laboratory,

Department of Molecular Physiology and Pharmacology, Tufts University

School of Medicine, 136 Harrison Avenue, Boston, MA 02111, USA

${ }^{3}$ Sackler School of Graduate Biomedical Sciences, Tufts University, Boston, MA 02111, USA

Full list of author information is available at the end of the article
}

anxiety seems to be present in at least a subgroup of patients with ASDs, who may also be more prone to stress [10].

We previously showed that corticotropin-releasing hormone $(\mathrm{CRH})$, secreted under stress, could induce release of vascular endothelial growth factor (VEGF) from human mast cells [11]. We found that the neuropeptide neuroten$\sin (\mathrm{NT})$, which is present in both the brain and gut, is significantly increased in the serum of young children with autism [12]. It is interesting that the distribution of NT receptors is more concentrated in the brain Broca area [13], which regulates speech, a function commonly lost in children with autism [14]. We also found that the serum of the same patients had higher levels of extracellular mitochondrial (mt)DNA [15], and NT stimulated release of extracellular mtDNA from human cultured mast cells [15]. We also found that the natural flavonoid luteolin can 
inhibit the ability of IgE [16] and mercury [17] to induce VEGF release from human mast cells.

In the current study, we investigated the effect of $\mathrm{CRH}$ and mitochondria on VEGF release from IgE/ anti-IgE-stimulated human mast cells, the effect of $\mathrm{CRH}$ on gene expression of the high affinity IgE receptor (FceRI), and the effect of the flavone luteolin on VEGF release.

\section{Methods}

The study was approved by the human institutional review board of Tufts Medical Center (Boston, MA, USA) under Exemption Number 4 for discarded samples without any identifiers.

\section{Culture of human mast cells}

Human umbilical cord blood was collected from mothers who had normal uncomplicated deliveries at Tufts Medical Center. Human cord blood-derived cultured mast cells (hCBMCs) were prepared using hematopoetic stem cells $\left(\mathrm{CD} 34^{+}\right)$isolated by positive selection of $\mathrm{CD}_{34}{ }^{+} / \mathrm{AC} 33^{+}$cells by magnetic cell sorting using an $\mathrm{AC} 133^{+}$cell isolation kit (Milletnyi Biotec, Auburn, CA, USA) as previously reported [18]. CD $34^{+}$cells were grown in serum-free expansion medium (StemSpan; StemCell Technologies, Vancouver, BC, Canada), supplemented with $100 \mathrm{ng} / \mathrm{ml}$ recombinant human stem cell factor (rhSCF; kindly supplied by Sweden Orphan Biovitrum AB, Stockholm, Sweden), $100 \mathrm{U} / \mathrm{ml}$ penicillin, $100 \mu \mathrm{g} / \mathrm{ml}$ streptomycin (Invitrogen, Carlsbad, CA, USA) and IL-3 (R\&D Systems, Minneapolis, MN, USA) for the first 3 weeks, then in the serum-free expansion medium with $50 \mathrm{ng} / \mathrm{ml} \mathrm{IL-6}$ (Peprotech, Rocky Hill, NJ, USA) and for 8 to 10 weeks, with fetal bovine serum (Invitrogen/Gibco, Carlsbad, CA, USA) added from week 6 . The purity of the hCBMCs was evaluated by immunocytochemical staining for tryptase [18]. hCBMCs cultured for 7 to 10 weeks were used for the experiments.

LAD2 cells (kindly supplied by Dr A.S. Kirshenbaum, National Institutes of Health, NIH, USA), derived from a human mast-cell leukemia cell line, were cultured in serum-free medium medium (StemPro ${ }^{\circledR}$-34; Invitrogen) supplemented with $100 \mathrm{U} / \mathrm{ml}$ penicillin/streptomycin and $100 \mathrm{ng} / \mathrm{ml}$ rhSCF (Sweden Orphan Biovitrum AB, Sweden).

\section{Mitochondrial preparation}

A commercial kit (Mitochondria Isolation Kit for Cells; Pierce Scientific, Rockford, IL, USA) was used to isolate mitochondria from cultured mast cells. Mitochondria were isolated under sterile conditions at $4^{\circ} \mathrm{C}$ in accordance with the manufacturer's instructions, and then subjected to sonication for 2 minutes at $4^{\circ} \mathrm{C}$ to release all inner components. The mtDNA and protein concentrations were determined by UV spectrophometry (NanoDrop 2000; Thermo Scientific, Waltham, MA, USA). The purity of the mitochondrial fraction was confirmed by the absence of glyceraldehyde 3-phosphate dehydrogenase (GAPDH) and lactate dehydrogenase (markers of microsomal contamination) and of $5^{\prime}$ nucleotidase and glucose-6-phosphatase (markers of cytoplasmic contamination).

\section{Vascular endothelial growth factor release assay}

VEGF secretion measured from LAD2 cells after pretreatment with CRH $(10 \mu \mathrm{mol} / \mathrm{l})$ for 24 hours, followed by 2 hours of incubation with $\operatorname{IgE}(1 \mathrm{microgram} / \mu \mathrm{l})$ in response to anti-IgE (10 microgram $/ \mu \mathrm{l})$. Human mast cells were treated with IgE $(1 \mu \mathrm{g} / \mathrm{ml})$ for 2 hours (Millpore, MA, USA), then washed, and luteolin $(100 \mu \mathrm{mol} / \mathrm{l})$ was added for 30 minutes before stimulation with mitochondria $(0.1$ and $10 \mathrm{microgram} / \mu \mathrm{l})$ and anti-IgE $(10 \mu \mathrm{g} /$ ml) (Dako, Carlsbad CA, USA). VEGF release was measured by ELISA (R\&D systems, Minneapolis, MN, USA) in the supernatant taken from control and stimulated hCBMC cultures.

\section{Quantitative PCR}

Total RNA from cultured mast cells and human skin biopsies was isolated using a commercial kit (RNeasy Mini Kit; Qiagen, Valencia, CA, USA) and reagent (Trizol; Invitrogen) respectively, in accordance with the manufacturer's instructions. Reverse transcription was performed with $300 \mathrm{ng}$ of total RNA using the iScript cDNA synthesis kit (BIO-RAD, Hercules, CA). To measure FceRI expression, cells were incubated for 6 hours with CRH (Sigma-Aldrich, MA, USA) and quantitative PCR was performed using Taqman gene expression assays (Applied Biosystems, Foster City, CA, USA). Samples were run at 45 cycles using a real-time PCR system (7300; Applied Biosystems). Relative mRNA abundance was determined from standard curves run with each experiment. mRNA gene expressions were normalized to GAPDH endogenous control. ( $\mathrm{Hu}$, VIC TAMRA; Applied Biosystems)

\section{Statistical analysis}

All experiments were performed in triplicate $(n=3)$ and repeated $(n=5)$. Results are presented as mean \pm SD. Data from stimulated and control samples were compared using the unpaired two-tailed, Student's t-test. $\mathrm{p}<0.05$ was considered significant.

\section{Results}

Because many children with autism have allergic symptoms are more anxious and over-react to stress, we investigated if CRH would affect allergic mast-cell activation. Addition of CRH $(10 \mu \mathrm{mol} / \mathrm{l})$ together with or after anti-IgE had no effect on anti-IgE-induced VEGF release (results not shown). Pretreatment of LAD2 cells for 24 
hours with CRH $(10 \mu \mathrm{mol} / \mathrm{l})$ followed by 2 hours of incubation with IgE augmented VEGF release in response to anti-IgE (Figure 1A). The amount of $\mathrm{CRH}$ required was high because LAD2 cells do not express many CRH receptors.

We then investigated if such augmentation might be due to increase in FceRI gene expression. Incubation of hCBMCs with $\mathrm{CRH}(0.1,1,10 \mu \mathrm{mol} / \mathrm{l})$ for 6 hours increased FceRI gene expression by almost five-fold (Figure 1B). Incubation of mast cells with CRH $(10 \mu \mathrm{mol} / \mathrm{l})$ for 48 hours increased FceRI gene expression by almost 200-fold (results not shown).

We then investigated the effect of mitochondria. Treatment of hCBMCs with sonicated mitochondria $(0.1$ and 10 microgram/ $\mu \mathrm{l}$ ) stimulated some VEGF release (Figure 2), but addition of mitochondria to anti-IgE-stimulated mast cells significantly increased VEGF release (Figure 2). Pretreatment with luteolin $(100 \mu \mathrm{mol} / \mathrm{l})$ for 30 minutes completely inhibited the VEGF release induced by mitochondria and anti-IgE, and even caused it to drop below basal levels (Figure 2).

\section{Discussion}

In this report, we show that CRH not only can augment allergic mast-cell release of VEGF, but can also induce FceRI expression in these human mast cells. Our finding is specific, because the peptide substance $\mathrm{P}$ had been shown previously to decrease FceRI gene expression [19], as also does lipopolysaccharide [20]. These results could explain how stress may worsen allergy-like symptoms in patients with ASDs $[6,8,21]$. It has previously been shown that CRH can augment NT-induced VEGF release [22]. Hence, CRH might augment both allergic and nonimmune mast-cell activation. The mechanism of such augmentation was not known.
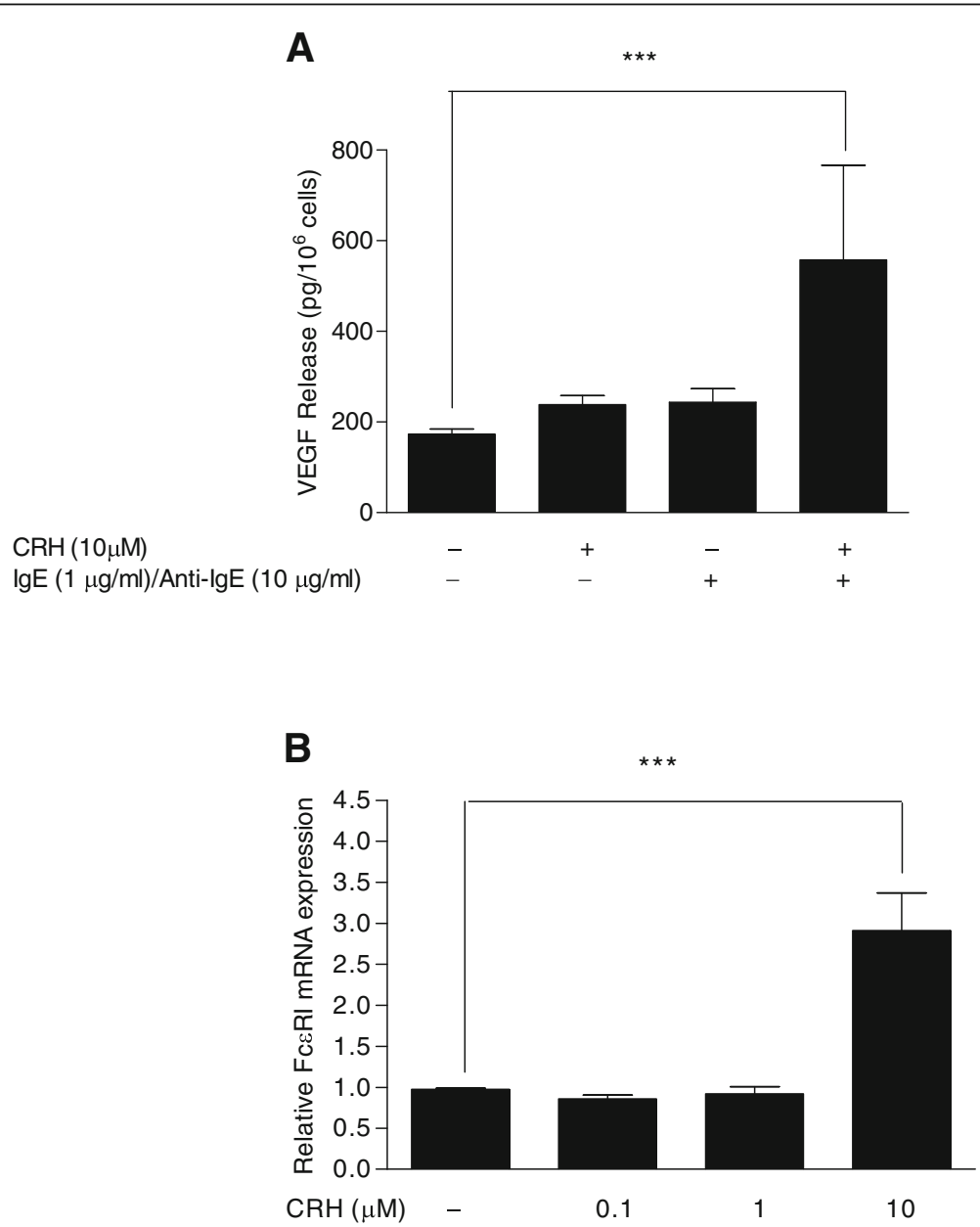

Figure $1 \mathrm{CRH}$ augments VEGF release from lgE/anti-lgE-stimulated human mast cells, and increases FcERI gene expression. (A) VEGF secretion from LAD2 cells was measured after pretreatment with CRH $10 \mu \mathrm{mol} / \mathrm{l}$ for 24 hours, followed by 2 hours of incubation with IgE 1 microgram $/ \mu$ in response to anti-lgE $10 \mu \mathrm{g} / \mathrm{ml}$. (B) FCERI mRNA expression was assessed after stimulation of hCBMCs with CRH $(0.1,1,10 \mu \mathrm{mol} /$ 1) for 6 hours. For all experiments, $n=5 ;{ }^{*} p<0.05$, ${ }^{* *} p<0.01,{ }^{* * *} p<0.001$ compared with control. 


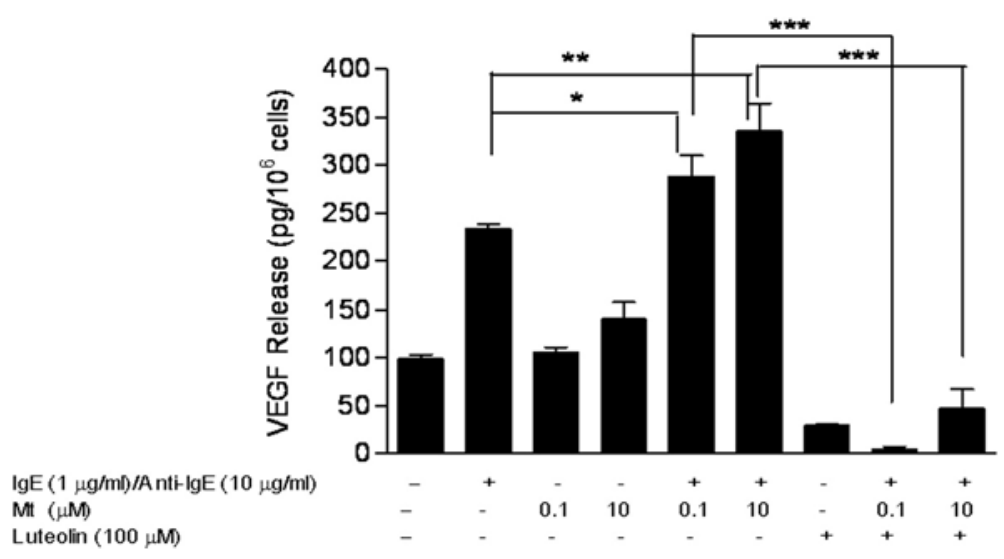

Figure 2 Mitochondria augment VEGF release from IgE/anti-lgE-stimulated human mast cells, and inhibition by luteolin. (A) VEGF secretion from hCBMCs was measured after pretreatment with lgE 1 microgram/ $\mu$ for 2 hours and then incubating with mitochondria ( 0.1 and 10 microgram/ $\mu \mathrm{l})$ and anti-lgE (10 microgram/ $\mu$ l) for 24 hours. Pretreatment with luteolin $100 \mu \mathrm{mol} / \mathrm{l}$ for 30 minutes completely inhibited VEGF release and dropped it even below basal levels. For all experiments, $n=5$; ${ }^{*} p<0.05,{ }^{* *} p<0.01$, ${ }^{* * *} p<0.001$ compared with control.

Increased anxiety seems to be present in at least a subgroup of patients with ASDs, who may also be more prone to stress [10]. A comparison of 34 adults with autism and 20 controls, matched for age, gender, and intellectual ability, found that patients with ASDs were three times as anxious as controls, and were significantly less able to cope with stress [23]. Acute stress can activate brain mast cells, an effect abolished by pretreatment with polyclonal antiserum to $\mathrm{CRH}$ [24]. Subsequently, CRH was reported to activate brain mast cells and increase blood-brain barrier permeability in rodents $[25,26]$, particularly in brain areas containing mast cells [27]. The direct effect of CRH was documented by intradermal administration leading to increased vascular permeability in rodents and humans, through activation of CRHR-1 [28].

We also found that sonicated mitochondrial components at $(10$ microgram $/ \mu \mathrm{l})$ stimulates VEGF release, which also augments allergic stimulation of VEGF release from human mast cells. At the present, we are not sure which mitochondrial components are responsible for VEGF release. They may include ATP, mtDNA, or formyl peptides found in mitochondria. VEGF is also known to stimulate mitochondrial biogenesis [29], suggesting a possible paracrine effect on secreted VEGF on the mitochondria of neighboring cells.

Several studies have reported mitochondrial dysfunction in autism [30], which may involved a subset of children with autism [31,32]. Mitochondria are the primary energy-generating organelles in eukaryotic cells, and they participate in multiple intracellular processes, including calcium buffering [33]. However, mitochondria were originally bacteria that became symbiotic with eukaryotic cells, and are typically prevented from being released extracellularly by autophagy [34]. We previously found increased extracellular mtDNA in the serum of young children with autism [15]. The present results indicate that extracellular mitochondria components can augment allergic mast-cell stimulation. This action may be in addition to any direct effect that mitochondrial components may have on the immune system. For instance, damageassociated mitochondrial pattern are able to activate Tolllike receptor 9 on human peripheral polymorphonuclear leukocytes, leading to release of interleukin-8 [35].

Given that ASDs has been associated with brain inflammation and oxidative stress $[1,3,36]$, we investigated the effect of the flavone luteolin, which has anti-inflammatory and anti-oxidant properties [37]. We found that luteolin $100 \mu \mathrm{mol} / \mathrm{l}$ was able to inhibit the augmenting effect at mitochondria on allergic human mast-cell activation. We used this concentration because it had been previously shown to cause maximal inhibition of mast cells and mast-cell-dependent stimulation of activated $T$ cells [16]. Luteolin also blocks methyl mercury-induced VEGF release from human mast cells [17]. Myricetin, the structural ana$\log$ of luteolin, can also inhibit mast-cell activation [38], and methyl mercury-induced mitochondrial dysfunction [39]. Luteolin also blocks activated peripheral blood mononuclear cells from patients with the inflammatory brain disease multiple sclerosis [40]. A new luteolin-containing dietary supplement was recently shown to have significant benefit in children with ASDs [41]. Luteolin may therefore be useful for the treatment of brain inflammation [40,42].

\section{Conclusion}

Augmentation of allergic and mitochondria-stimulated mast-cell activation by CRH secreted by stress may explain at least some of the symptoms of patients with 
ASDs [43,44]. Other environmental triggers may also contribute ASDs $[45,46]$, and to 'mast-cell activation syndrome' [47]. Luteolin may provide some degree of protection against these.

\section{Abbreviations \\ ASDs: Autism spectrum disorders; CRH: Corticotropin-releasing hormone; DPBS: Dulbecco's phosphate-buffered saline; ELISA: Enzyme-linked immunosorbent assay; FBS: Fetal bovine serum; hCBMCs: Human umbilical cord blood-derived cultured mast cells; NT: Neurotensin; rhSCF: Recombinant human stem cell factor; VEGF: Vascular endothelial growth factor.}

\section{Competing interest}

The authors declared that they have no competing interest.

\section{Acknowledgments}

We thank Sweden Orphan Biovitrum AB (Stockholm, Sweden) for the kind supply of rhSCF, and Dr Errol Norwitz (Department of Obstetrics and Gynecology, Tufts Medical Center) for the supply of umbilical cord blood. Some parts of the work described above were funded by Safe Minds/Autism Research Collaboration and the National Autism Association.

\section{Author details}

'Molecular Immunopharmacology and Drug Discovery Laboratory, Department of Molecular Physiology and Pharmacology, Tufts University School of Medicine, 136 Harrison Avenue, Boston, MA 02111, USA. ${ }^{2}$ Department of Pharmacy, Tufts Medical Center, Boston, MA 02111, USA. ${ }^{3}$ Sackler School of Graduate Biomedical Sciences, Tufts University, Boston, MA 02111, USA. ${ }^{4}$ Department of Biochemistry, Tufts University School, Boston, MA 02111, USA. ${ }^{5}$ Department of Internal Medicine, Tufts University School of Medicine and Tufts Medical Center, Boston, MA 02111, USA. ${ }^{6}$ Department of Psychiatry, Tufts University School of Medicine and Tufts Medical Center, Boston, MA 02111, USA.

\section{Authors' contributions}

TCT and SA prepared, read, and approved this manuscript.

\section{Disclosures}

TCT is the inventor of US patents Number $6,624,148 ; 6,689,748 ; 6,984,667$, and EPO 1365777, which cover methods and compositions of mast-cell blockers, including flavonoids, US patents 7,906,153 and 12/861,152 (allowed) for treatment of neuro-inflammatory conditions, and US patent applications Number12/534,571 and Number13/009,282 for the diagnosis and treatment of ASDs. TCT is also the inventor of the dietary supplement, NeuroProtek ${ }^{\circledR}$, which has the US trademark No 3,225,924.

\section{Received: 14 February 2012 Accepted: 4 May 2012}

Published: 4 May 2012

\section{References}

1. Ashwood P, Wills S, Van de Water J: The immune response in autism: a new frontier for autism research. J Leukoc Biol 2006, 80:1-15.

2. Atladottir HO, Pedersen MG, Thorsen P, Mortensen PB, Deleuran B, Eaton WW, Parner ET: Association of family history of autoimmune diseases and autism spectrum disorders. Pediatrics 2009, 124:687-694.

3. Theoharides TC, Kempuraj D, Redwood L: Autism: an emerging 'neuroimmune disorder' in search of therapy. Exp Opinion on Pharmacotherapy 2009, 10:2127-2143.

4. Theoharides TC, Kempuraj D, Tagen M, Conti P, Kalogeromitros D: Differential release of mast cell mediators and the pathogenesis of inflammation. Immunol Rev 2007, 217:65-78.

5. Gurney JG, McPheeters ML, Davis MM: Parental report of health conditions and health care use among children with and without autism: National Survey of Children's Health. Arch Pediatr Adolesc Med 2006, 160:825-830.

6. Jyonouchi H, Geng L, Cushing-Ruby A, Quraishi H: Impact of innate immunity in a subset of children with autism spectrum disorders: a case control study. J Neuroinflammation 2008, 5:52.

7. Bakkaloglu B, Anlar B, Anlar FY, Oktem F, Pehlivanturk B, Unal F, Ozbesler C, Gokler B: Atopic features in early childhood autism. Eur $J$ Paediatr Neurol 2008, 12:476-479.
8. Magalhaes ES, Pinto-Mariz F, Bastos-Pinto S, Pontes AT, Prado EA, Deazevedo LC: Immune allergic response in Asperger syndrome. I Neuroimmunol 2009, 216:108-112

9. Angelidou A, Alysandratos KD, Asadi S, Zhang B, Francis K, Vasiadi M, Kalogeromitros D, Theoharides TC: Brief report: "allergic symptoms" in children with autism spectrum disorders. more than meets the eye? Autism Dev Disord 2011, 41:1579-1585.

10. White SW, Oswald D, Ollendick T, Scahill L: Anxiety in children and adolescents with autism spectrum disorders. Clin Psychol Rev 2009, 29:216-229.

11. Cao J, Papadopoulou N, Kempuraj D, Boucher WS, Sugimoto K, Cetrulo CL, Theoharides TC: Human mast cells express corticotropin-releasing hormone (CRH) receptors and $\mathrm{CRH}$ leads to selective secretion of vascular endothelial growth factor. J Immunol 2005, 174:7665-7675.

12. Angelidou A, Francis K, Vasiadi M, Alysandratos K-D, Zhang B, Theoharides A, Lykouras $L$, Kalogeromitros $D$, Theoharides TC: Neurotensin is increased in serum of young children with autistic disorder. J Neuroinflammation 2010, 7:48.

13. Fassio A, Evans G, Grisshammer R, Bolam JP, Mimmack M, Emson PC: Distribution of the neurotensin receptor NTS1 in the rat CNS studied using an amino-terminal directed antibody. Neuropharmacology 2000, 39:1430-1442.

14. Boucher J: Research Review: Structural language in autistic spectrum disorder - characteristics and causes. J Child Psychol Psychiatry 2012, 53:219-233.

15. Zhang $B$, Angelidou A, Alysandratos KD, Vasiadi M, Francis $K$, Asadi $S$, Theoharides A, Sideri K, Lykouras L, Kalogeromitros D, Theoharides TC: Mitochondrial DNA and anti-mitochondrial antibodies in serum of autistic children. J Neuroinflammation 2010, 7:80.

16. Kempuraj D, Tagen M, lliopoulou BP, Clemons A, Vasiadi M, Boucher W, House M, Wolferg A, Theoharides TC: Luteolin inhibits myelin basic protein-induced human mast cell activation and mast cell dependent stimulation of Jurkat T cells. Br J Pharmacol 2008, 155:1076-1084.

17. Asadi S, Zhang B, Weng Z, Angelidou A, Kempuraj D, Alysandratos KD, Theoharides TC: Luteolin and thiosalicylate inhibit $\mathrm{HgCl}(2)$ and thimerosal-induced VEGF release from human mast cells. Int $\mathrm{J}$ Immunopathol Pharmacol 2010, 23:1015-1020.

18. Kempuraj D, Saito H, Kaneko A, Fukagawa K, Nakayama M, Toru H, Tomikawa M, Tachimoto H, Ebisawa M, Akasawa A, Miyagi T, Kimura H, Nakajima T, Tsuji K, Nakahata T: Characterization of mast cell-committed progenitors present in human umbilical cord blood. Blood 1999, 93:3338-3346.

19. McCary C, Tancowny BP, Catalli A, Grammer LC, Harris KE, Schleimer RP, Kulka M: Substance $P$ downregulates expression of the high affinity lgE receptor (FcepsilonRI) by human mast cells. J Neuroimmunol 2010, 220:17-24.

20. Kirshenbaum AS, Swindle E, Kulka M, Wu Y, Metcalfe DD: Effect of lipopolysaccharide (LPS) and peptidoglycan (PGN) on human mast cell numbers, cytokine production, and protease composition. BMC Immunol 2008, 9:45

21. Theoharides TC, Angelidou A, Alysandratos KD, Zhang B, Asadi S, Francis K, Toniato E, Kalogeromitros D: Mast cell activation and autism. Biochim Biophys Acta 2012, 1822(1):34-41.

22. Donelan J, Boucher W, Papadopoulou N, Lytinas M, Papaliodis D, Theoharides TC: Corticotropin-releasing hormone induces skin vascular permeability through a neurotensin-dependent process. Proc Natl Acad Sci USA 2006, 103:7759-7764.

23. Gillott A, Standen PJ: Levels of anxiety and sources of stress in adults with autism. J Intellect Disabil 2007, 11:359-370.

24. Ercan F, San T, Cavdar S: The effects of cold-restraint stress on urinary bladder wall compared with interstitial cystitis morphology. Urol Res 1999, 27:454-461.

25. Esposito P, Chandler N, Kandere-Grzybowska K, Basu S, Jacobson S, Connolly $\mathrm{R}$, Tutor D, Theoharides TC: Corticotropin-releasing hormone (CRH) and brain mast cells regulate blood-brain-barrier permeability induced by acute stress. J Pharmacol Exp Ther 2002, 303:1061-1066.

26. Theoharides TC, Konstantinidou A: Corticotropin-releasing hormone and the blood-brain-barrier. Front Biosci 2007, 12:1615-1628.

27. Esposito P, Gheorghe D, Kandere K, Pang X, Conally R, Jacobson S, Theoharides TC: Acute stress increases permeability of the blood-brain-barrier through activation of brain mast cells. Brain Res 2001, 888:117-127. 
28. Theoharides TC, Singh LK, Boucher W, Pang X, Letourneau R, Webster E, Chrousos G: Corticotropin-releasing hormone induces skin mast cell degranulation and increased vascular permeability, a possible explanation for its pro-inflammatory effects. Endocrinology 1998, 139:403-413.

29. Wright GL, Maroulakou IG, Eldridge J, Liby TL, Sridharan V, Tsichlis PN, Muise-Helmericks RC: VEGF stimulation of mitochondrial biogenesis: requirement of AKT3 kinase. FASEB J 2008, 22:3264-3275.

30. Palmieri L, Persico AM: Mitochondrial dysfunction in autism spectrum disorders: Cause or effect? Biochim Biophys Acta 2010, 1797:1130-1137.

31. Weissman JR, Kelley RI, Bauman ML, Cohen BH, Murray KF, Mitchell RL, Kern RL, Natowicz MR: Mitochondrial disease in autism spectrum disorder patients: A cohort analysis. PLoS One 2008, 3:e3815.

32. Frye RE, Rossignol DA: Mitochondrial dysfunction can connect the diverse medical symptoms associated with autism spectrum disorders. Pediatr Res 2011, 69:41R-47R.

33. Chan DC: Mitochondria: dynamic organelles in disease, aging, and development. Cell 2006, 125:1241-1252.

34. Twig G, Hyde B, Shirihai OS: Mitochondrial fusion, fission and autophagy as a quality control axis: the bioenergetic view. Biochim Biophys Acta 2008 1777:1092-1097.

35. Zhang $Q$, Raoof $M$, Chen Y, Sumi Y, Sursal T, Junger W, Brohi K, Itagaki $K$, Hauser CJ: Circulating mitochondrial DAMPs cause inflammatory responses to injury. Nature 2010, 464:104-107.

36. Goines P, Van de Water J: The immune system's role in the biology of autism. Curr Opin Neurol 2010, 23:111-117.

37. Middleton E Jr, Kandaswami C, Theoharides TC: The effects of plant flavonoids on mammalian cells: implications for inflammation, heart disease and cancer. Pharmacol Rev 2000, 52:673-751.

38. Kempuraj D, Madhappan B, Christodoulou S, Boucher W, Cao J, Papadopoulou N, Cetrulo CL, Theoharides TC: Flavonols inhibit proinflammatory mediator release, intracellular calcium ion levels and protein kinase $\mathrm{C}$ theta phosphorylation in human mast cells. $\mathrm{Br} J$ Pharmacol 2005, 145:934-944.

39. Franco JL, Posser T, Missau F, Pizzolatti MG, Dos Santos AR, Souza DO, Aschner M, Rocha JB, Dafre AL, Farina M: Structure-activity relationship of flavonoids derived from medicinal plants in preventing methylmercuryinduced mitochondrial dysfunction. Environ Toxicol Pharmacol 2010, 30:272-278.

40. Theoharides TC: Luteolin as a therapeutic option for multiple sclerosis. $J$ Neuroinflammation 2009, 6:29.

41. Theoharides TC, Asadi S, Panagiotou JP: Effect of a luteolin formulation (NeuroProtek) on autism spectrum disorders-A case series. Int $\mathrm{J}$ Immunopathol and Pharmacol 2012,. 25(2):00-00.

42. Theoharides TC, Zhang B: Neuro-inflammation, blood-brain barrier. Seizures and Autism I Neuroinflammation. 2011, 8:168.

43. Theoharides TC, Doyle R, Francis K, Conti P, Kalogeromitros D: Novel therapeutic targets for autism. Trends Pharmacol Sci 2008, 29:375-382.

44. Theoharides TC, Angelidou A, Alysandratos KD, Zhang B, Asadi S, Francis K, Toniato E, Kalogeromitros D: Mast cell activation and autism. Biochim Biophys Acta 1822, 2012:34-41.

45. Deth R, Muratore C, Benzecry J, Power-Charnitsky VA, Waly M: How environmental and genetic factors combine to cause autism: A redox/ methylation hypothesis. Neurotoxicology 2008, 29:190-201.

46. Herbert MR: Contributions of the environment and environmentally vulnerable physiology to autism spectrum disorders. Curr Opin Neurol 2010, 23:103-110.

47. Hamilton MJ, Hornick JL, Akin C, Castells MC, Greenberger NJ: Mast cell activation syndrome: a newly recognized disorder with systemic clinical manifestations. J Allergy Clin Immunol 2011, 128:147-152.

doi:10.1186/1742-2094-9-85

Cite this article as: Asadi and Theoharides: Corticotropin-releasing hormone and extracellular mitochondria augment IgE-stimulated human mast-cell vascular endothelial growth factor release, which is inhibited by luteolin. Journal of Neuroinflammation 2012 9:85.

\section{Submit your next manuscript to BioMed Central and take full advantage of:}

- Convenient online submission

- Thorough peer review

- No space constraints or color figure charges

- Immediate publication on acceptance

- Inclusion in PubMed, CAS, Scopus and Google Scholar

- Research which is freely available for redistribution

Submit your manuscript at www.biomedcentral.com/submit
() Biomed Central 